\title{
Predicting frequent COPD exacerbations using primary care data [Corrigendum]
}

Kerkhof M, Freeman D, Jones R, Chisholm A, Price DB. Int J Chron Obstruct Pulmon Dis. 2015;10:2439-2450.

Page 2450, the formula shown in the Supplementary materials is incorrect. The correct formula is shown below.

The formula: Risk of $\geq 2$ COPD exacerbations within the next 12 months $=1 /\{1+\exp [-(-0.7306+0.8840 \times$ 1 previous exacerbation in last 12 months $+1.4786 \times 2$ previous exacerbations in last 12 months $+1.9857 \times 3$ previous exacerbations in last 12 months $+2.8811 \times \geq 4$ previous exacerbations in last 12 months $-0.0093 \times \mathrm{FEV}_{1} \%$ predicted + $0.0360 \times$ age $-0.0004 \times$ age $^{2}-1.2194 \times$ height (in meter) + $0.2518 \times$ (blood eosinophil count $\geq 400 / \mu \mathrm{L}$ in a patient who is not currently smoking) $+0.2953 \times$ any evidence of asthma $\times$ $0.3018 \times$ history of non-allergic rhinitis $+0.3298 \times$ history of nasal polyps $+0.1164 \times$ history of ischemic heart disease + $0.1071 \times$ history of anxiety or depression $+0.1689 \times$ history of GERD)] \}. For the yes/no variables, a value of 1 should be used for "yes" and a value of 0 for "no."
International Journal of COPD

\section{Publish your work in this journal}

The International Journal of COPD is an international, peer-reviewed journal of therapeutics and pharmacology focusing on concise rapid reporting of clinical studies and reviews in COPD. Special focus is given to the pathophysiological processes underlying the disease, intervention programs, patient focused education, and self management protocols.

\section{Dovepress}

This journal is indexed on PubMed Central, MedLine and CAS. The manuscript management system is completely online and includes a very quick and fair peer-review system, which is all easy to use. Visit http://www.dovepress.com/testimonials.php to read real quotes from published authors.

Submit your manuscript here: http://www.dovepress.com/international-journal-of-chronic-obstructive-pulmonary-disease-journal 